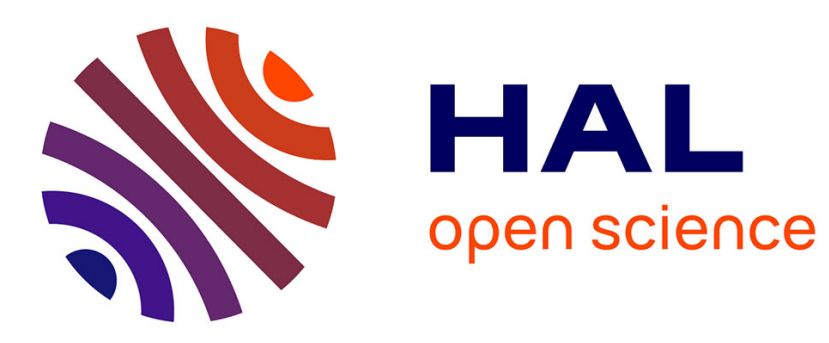

\title{
Measuring of some selected herbicides in paddy surface water in the Saijo Basin, Western Japan
}

\author{
Sultana Parveen, Testuyuki Kohguchi, Hideki Shimazawa, Nobukazu \\ Nakagoshi
}

\section{- To cite this version:}

Sultana Parveen, Testuyuki Kohguchi, Hideki Shimazawa, Nobukazu Nakagoshi. Measuring of some selected herbicides in paddy surface water in the Saijo Basin, Western Japan. Agronomy for Sustainable Development, 2005, 25 (1), pp.55-61. hal-00886253

\section{HAL Id: hal-00886253 https://hal.science/hal-00886253}

Submitted on 1 Jan 2005

HAL is a multi-disciplinary open access archive for the deposit and dissemination of scientific research documents, whether they are published or not. The documents may come from teaching and research institutions in France or abroad, or from public or private research centers.
L'archive ouverte pluridisciplinaire HAL, est destinée au dépôt et à la diffusion de documents scientifiques de niveau recherche, publiés ou non, émanant des établissements d'enseignement et de recherche français ou étrangers, des laboratoires publics ou privés. 


\title{
Measuring of some selected herbicides in paddy surface water in the Saijo Basin, Western Japan
}

\author{
Sultana PARVEEN ${ }^{a *}$, Testuyuki KOHGUCHI ${ }^{\mathrm{b}}$, Hideki SHIMAZAWA ${ }^{\mathrm{b}}$, Nobukazu NAKAGOSHI ${ }^{\mathrm{c}}$ \\ ${ }^{a}$ Graduate School for International Development and Cooperation (IDEC), Hiroshima University, Kagamiyama 1-5-1, Higashi Hiroshima 739-8529, Japan \\ ${ }^{\mathrm{b}}$ Hiroshima Prefecture Agriculture Research Center, Hara, Hachihonmatu, Higashi Hiroshima 739-0151, Japan \\ ${ }^{\mathrm{c}}$ Dept. of Environmental Studies, IDEC, Hiroshima University, Higashi Hiroshima, 739-8529, Japan
}

(Received 31 March 2003; accepted 25 August 2004)

\begin{abstract}
An analysis of the dissipation of herbicides was done in paddy water and in drainage channels of farm paddies as well as in experimental plots. A field study was conducted in three selected paddy farms of Higashi Hiroshima and an experiment was carried out in the Hiroshima Prefecture Agriculture Research Center in the paddy season of the year 2002. The herbicides were mefenacet, thiobencarb, pyributicarb and cyhalofop -butyl. The sample water was analyzed by using gas chromatography after solid phase extraction. The maximum concentration of all herbicides was detected within 1 to 3 days after herbicide application and became trace level after 21 to 28 days. The highest amount of herbicide detected was $338 \mu \mathrm{g} / \mathrm{L}$ mefenacet in Farm B. No cyhalofop-butyl was detected in the experiment but was found in farm paddies until 7 days. Thiobencarb was detected until 21 and 28 days, respectively, in farm paddies and in the experiment. Pyributicarb was detected until 28 days in farm paddies and in the experiment. We found that the concentration of all herbicides in drainage channels was comparable with the paddy field at 1 day and 3 days and thiobencarb at 1 day.
\end{abstract}

herbicides / paddy surface water / drainage / dissipation / Saijo basin

\section{INTRODUCTION}

Currently, great emphasis is being given to the environmental fate of agricultural pesticides. Herbicides, being important agricultural chemicals, are one of the targets of environmental concern. To be more effective, many herbicides need to kill more weed species, for which most of the herbicides should stay in the soil and water for a longer period of time. However, excessive persistence of herbicides in soil and water may pose a great threat to the environment.

The environmental burden of herbicides applied in paddy fields is heaviest in water. Rice herbicides are applied directly to surface water on the paddy fields; the paddy field system is extremely susceptible to herbicide runoff upon significant rainfall events or inappropriate water management. Irrigation drainage and runoff flow sequentially from the paddy fields to irrigation channels, small rivers and large rivers, whereby they are dispersed widely throughout the water systems, and carry herbicides used in rice fields [9]. In Japan, the runoff rate into water systems is higher than $1 \%$ of herbicides applied to upland fields [20]. In the case of paddy fields, continuous irrigation and drainage management practices may have significant runoff losses of up to $38 \%$ of applied herbicide [21]. Herbicides used in paddy fields are often detected in river water from May to July after the pesticide application. The highest herbicide con- centration in paddy water appears between the time immediately following application and the following day, and the greater the herbicide water solubility, the higher the concentration in the paddy water tends to be. The half-life of herbicides in paddy water is $2-5$ days for nearly all herbicides used in Japan.

The drainage from paddy field areas in Japan was monitored for a 5-year period and 12 herbicides, 5 insecticides and 5 fungicides were detected [14]. The concentration ranged from 1 to $1000 \mathrm{ppb}$; the low concentration was associated with long exposure (1-3 months) and high concentration with short exposure (one week). The runoff rates differed depending upon herbicide properties and environmental conditions, such as rainfall and temperature, as well as amounts used per unit area and paddy water management methods. High rainfall immediately after herbicide application, as well as flow irrigation, will increase the runoff rate into water systems. Recently, concern has arisen that runoff of pesticides applied to agricultural land may cause contamination of surface water sources and have adverse effects on aquatic ecosystems. In Japan, more than half of all agricultural lands are paddy fields, where applied pesticides can easily flow out through paddy field water to public water areas. Considering this situation, Japanese regulatory agencies have established water quality regulations and standards for pesticides [11].

\footnotetext{
* Corresponding author: parveen_sultana04@yahoo.com
} 


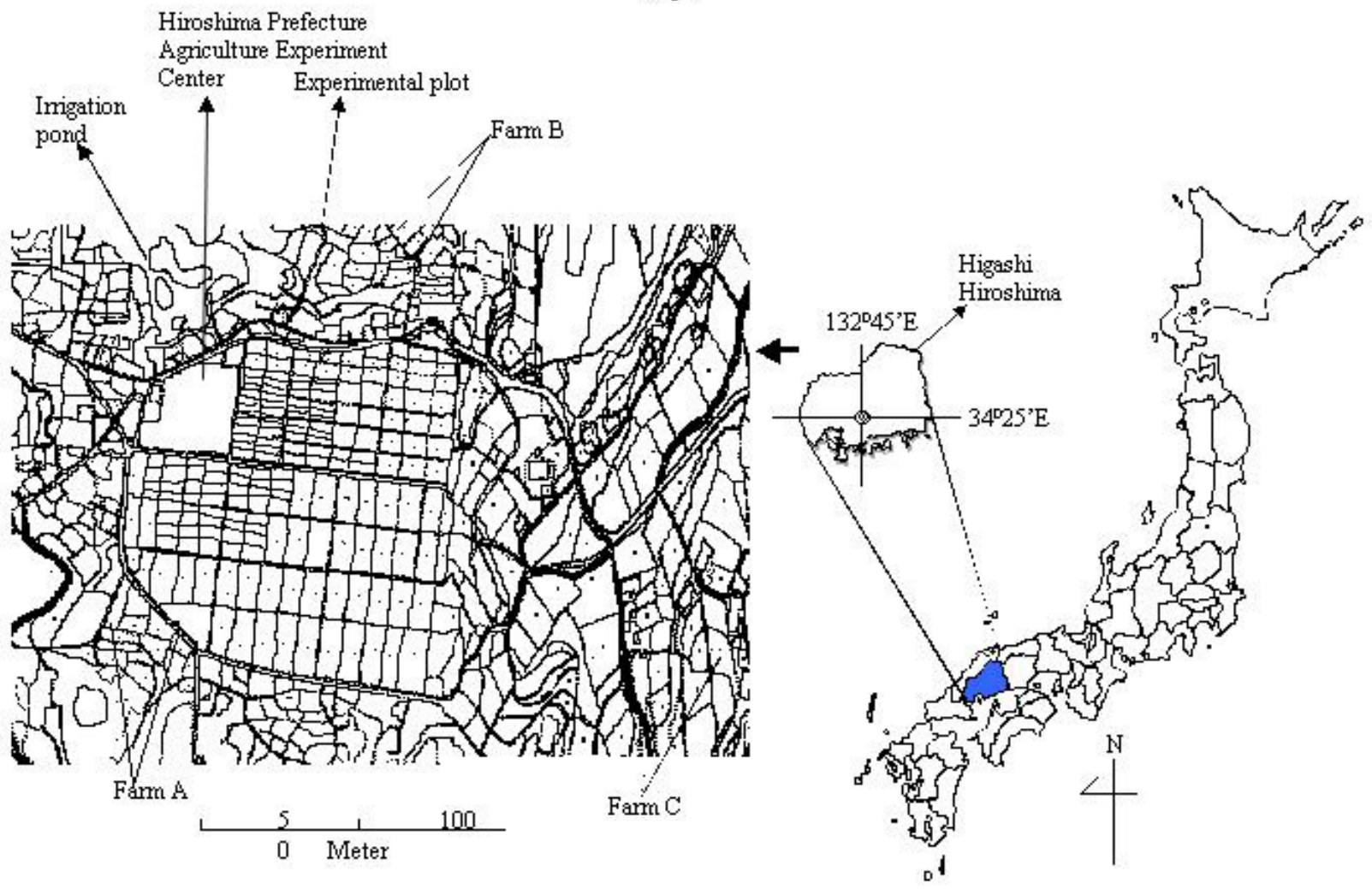

Figure 1. Location of the study area. The dotted areas represent the paddy fields.

A study of Itagaki et al. [10] detected 18 pesticides in the Minaga River and Minaga Reservoir of Higashi Hiroshima City of Hiroshima Prefecture during July-October 1997 and September-November 1998. All of the pesticides had been used in paddy fields. Another study revealed that the surveyed farmers used 10 out of those 18 pesticides in their fields in the 2000 paddy season [16]. A study by Hayase et al. [7] detected some pesticides in paddy fields of Higashi Hiroshima where no pesticides had been applied, indicating contamination by pesticides from surrounding paddy fields. Most studies have reported the presence of the herbicides mefenacet, pyributicarb and thiobencarb in rivers, ponds or reservoirs $[15,18,19]$. Dissipation rates of herbicides after application provide important information for the assessment of the behavior of their residue [1]. Therefore, it is important to conduct studies on the dissipation of herbicides in farm paddy water, as well as in drainage water, and relate this to the environmental consequences. This study will analyze pesticide dissipation in the paddy water under farmers 'management conditions and compare with the experiment by using standard management practices.

\section{MATERIALS AND METHODS}

\subsection{Study area}

The study was conducted in three selected farm paddies of Higashi Hiroshima City of Hiroshima prefecture, Japan (Fig. 1).
Only $3.2 \%$ of the city's populations are engaged in farming activities and only $0.5 \%$ of the farming populations are fulltime farmers. The city area is $288.25 \mathrm{~km}^{2}$, of which about $12 \%$ is agricultural land, and about $95 \%$ of that agricultural land is under paddy cultivation. The altitude is approximately $200 \mathrm{~m}$ above sea level and the city is located in the Saijo basin under the Kurose watershed, which is surrounded by mountains of about $500 \mathrm{~m}$ above sea level. The mean annual rainfall of this area was $1071 \mathrm{~mm}$ in 2002, and the corresponding mean annual temperature ranged from $3.3{ }^{\circ} \mathrm{C}$ in January to $26.4{ }^{\circ} \mathrm{C}$ in July. The soil type of the basin is sandy loam with $15.5 \%$ clay content and $1.89 \%$ humus. The cation exchange capacity (CEC) varies from 8.6 to $11.0 \mathrm{meq} / 100 \mathrm{~g}$ soil. The water $\mathrm{pH}$ of the study paddy fields were acidic at the early stage and acidic to neutral at the later stage, varying from 6.2 to 7.5. The minimum temperature of paddy water was $18.2^{\circ} \mathrm{C}$ in early May and rose to $32.5^{\circ} \mathrm{C}$ in early June. The study area can be regarded as a typical paddy cultivating area in Japan.

\subsection{Herbicide application and water management}

The herbicides selected are widely used by the farmers of Hiroshima prefecture. Mefenacet was common in all three herbicides used by the farmers, and this is contained in about $50 \%$ of the commercial herbicides used in Hiroshima prefecture, as per use statistics for 2001. On the basis of herbicide use, three commercial and full-time farmers were selected from the study 
area, keeping the homogeneity of soil conditions, micro-climatic conditions and sources of irrigation water the same as the Hiroshima Prefecture Agriculture Research Center. The selected farms were designated as Farm A, Farm B and Farm C. The commercial herbicides were: Ulfues $1 \mathrm{~kg}$ granule 51 (Kumiai) containing mefenace $3.0 \%$, thiobencarb $15 \%$ and bensulfuron methyl $0.51 \%$; Longet flowable (Takeda) containing mefenacet $8 \%$, pyributicarb $10 \%$, dymron $18 \%$ and imazosulfuron $1.5 \%$, and Inegreen (Hokko) containing mefenacet $7.5 \%$, cyhalofopbutyl $1.5 \%$, dymron $4.5 \%$ and bensulfuron methyl $0.51 \%$. Farm A, Farm B and Farm C used Ulfues, Longet flowable and Inegreen, respectively. Along with mefenacet as the common compound, thiobencarb for Ulfues, pyributicarb for Longet flowable and cyhalofop-butyl for Inegreen were analyzed on the basis of the method used in this study. Among these herbicides, mefenacet was the second most widely used in paddy fields all over Japan and in our study area. Bensulfuron methyl is the most common compound found in any formulation. Thiobencarb and pyributicarb are also widely used paddy herbicides. Cyhalofop-butyl (Clincher) is also a special herbicide, which is usually used by the farmers for spot control of paddy weeds.

The paddy fields of the farms studied were those having direct inlets and outlets with irrigation and drainage channels, and it was not possible for drainage water from other paddy fields to enter. In Japan, drainage water from paddy fields is used repeatedly in other paddy fields downstream and the movement of herbicide residues from other fields occurs. At least two paddy fields of $1000 \mathrm{~m}^{2}$ (10 a) were studied for each of the farms. In addition, an experiment was conducted using the same herbicide under standard management practices to measure the rate of herbicide dissipation in the paddy field as compared with farm paddies under farmers' management condition. All the operations (from land preparation to herbicide application and water management) of the studied farm paddies were conducted by the farmers. Water samples were collected from the selected paddies for analysis and other relevant information also gathered from them. On the other hand, in the experimental plots all operations were done by our research team and strictly maintained recommended practice for water management (such as controlled drainage until 10 days after application) and herbicide application.

All experiments were conducted at the experimental station of Hiroshima Prefecture Agriculture Research Center in Higashi Hiroshima from May to July 2002. During the experiment, the plots $(3 \mathrm{~m} \times 6 \mathrm{~m})$ with 2 replications and 1 control for each of the herbicides were planted with rice (Oryza sativa L. Koshihikari). Commercial granular formulation of Ulfues and Inegreen $1 \mathrm{~kg} / 1000 \mathrm{~m}^{2}$ and Emulsifiable Concentrate of Longet Flowable $500 \mathrm{~mL} / 1000 \mathrm{~m}^{2}$ were used. The herbicides were applied within one week after transplanting by sprayer.

The paddy farms of the study area usually use pond irrigation where rainwater is retained and connected to the paddy fields. The water from the pond runs through the irrigation channel to the paddy field and all the paddy fields are again connected to the drainage channel and ultimately to the river. Not all farm paddies are artificially constructed and strictly maintained. It is recommended that for at least 10 days after herbicide application draining be restricted. But due to field conditions and rainfall, the farmers seldom maintain this. Therefore, overflow
Table I. Water conditions of the study paddy fields.

\begin{tabular}{|c|c|c|c|}
\hline & Farm A & Farm B & Farm C \\
\hline Area $\left(\mathrm{m}^{2}\right)$ & 1000 & 1000 & 1000 \\
\hline Average depth of water $(\mathrm{cm})$ & 3.5 & 3.6 & 4.5 \\
\hline Field water volume $\left(\mathrm{m}^{3}\right)$ & 35 & 36 & 45 \\
\hline Outflow rate of water $\left(\mathrm{m}^{3} /\right.$ day $)$ & 7.7 & 6.7 & 5.6 \\
\hline Penetration rate of water ( $\mathrm{m}^{3} /$ day) & 0.95 & 0.76 & 0.7 \\
\hline Evaporation rates of water $(\mathrm{cm} /$ day $)$ & 0.14 & 0.01 & 0.89 \\
\hline \multicolumn{4}{|l|}{$\mathrm{p}^{\mathrm{H}}$ of the water } \\
\hline Minimum & 6.2 & 6.3 & 6.3 \\
\hline Maximum & 7.5 & 7.5 & 7.4 \\
\hline \multicolumn{4}{|l|}{ Water temperature } \\
\hline Minimum & 18.2 & 16.8 & 19.2 \\
\hline Maximum & 32 & 28.2 & 32.5 \\
\hline
\end{tabular}

and draining of paddy water are common even immediately after herbicide application.

During the study period, the inflow and outflow rates of water, water depth and evaporation rate of water were measured at each sampling time. The water conditions of each paddy field are shown in Table I.

\subsection{Samplings}

The sampling was done at or around 1, 3, 7, 14, 21, 28 and 35 days after herbicide application. Two samples were taken from random spots in each of the paddy fields ( 4 for 2 paddy fields) and the experiment plots ( 4 for 2 replications). From each of the fields and plots $1000 \mathrm{~mL}$ samples were collected during the whole study period. In the same way, water from the drainage channel was also collected. The water samples were brought to the laboratory immediately and analyzed using gas chromatography after solid phase extraction. The method used for the residue analysis was developed at the Pesticide Analysis Laboratory of Hiroshima Prefecture Agriculture Experimental Center. The samples from all the fields and plots were analyzed before application of herbicides to check the residue from the previous year or irrigation water.

\subsection{Analysis of the samples}

A Sep-Pak Cartridge Rack (Nippon Millipore Co.) was used for solid phase extraction and elution. Herbicides and other reagents were purchased from Kanto Chemicals (Japan). All solvents used were of pesticide residue-grade. Water samples were filtered through No. 7 filter paper of $4 \mu \mathrm{m}$ pore size with Hyflo-Super-Cel (Kiriyama, Japan) to remove the particles. Sep Pak-PS2 (C18) cartridges (Waters, Ireland), 2 per sample, were preconditioned by washing with $10 \mathrm{~mL}$ acetonitrile and $30 \mathrm{~mL}$ distilled water and dried with a water aspirator. A $200 \mathrm{~mL}$ volume of filtered water with 2 repetitions of each sample was passed through the cartridge at a flow rate of $10 \mathrm{~mL} / \mathrm{min}$. The herbicides trapped on the cartridge were eluted with $10 \mathrm{~mL}$ of acetonitrile. The elutes were passed through Sodium Sulfate by phase separators silicone-treated filter paper $(15.0 \mathrm{~cm}$ diameter, Whatman) to remove water. Then the elutes were concentrated to $1 \mathrm{~mL}$ by using a rotary evaporator, followed by nitrogen gas concentration until dried. The extracts were then 
redissolved in $1 \mathrm{~mL}$ acetone and the resulting solution was analyzed by using a gas chromatograph.

A Shimadzu GC - 14A gas chromatograph with FTD - 8 (Flame Thermionic Detector) was used for the analysis. The glass column was a chromosorb (w) HP (i.d. $3 \mathrm{~mm}$ and length $1.0 \mathrm{~m}$ ) with $1.5 \%$ silicone OV-17 and $1.95 \%$ silicone DC QF-1. The column temperature was $190{ }^{\circ} \mathrm{C}$ for 4 minutes, with an increase of $30^{\circ} \mathrm{C} / \mathrm{min}$ and the final temperature was $230{ }^{\circ} \mathrm{C}$ for 11 minutes, with an injection temperature of $250^{\circ} \mathrm{C}$, and a detector temperature of $280{ }^{\circ} \mathrm{C}$. The $\mathrm{GC}$ was equipped with an automatic sampler with the injection volume set to $2 \mu \mathrm{L}$. The temperature program was the same for all the herbicides. The recovery for thiobencarb was $96.5 \%($ S.D. $=3.6, \mathrm{n}=4), 93.1 \%$ for mefenacet $($ S.D. $=4.3, \mathrm{n}=4), 91 \%$ for pyributicarb $(($ S.D. $=$ $3.3, \mathrm{n}=4)$ and $95 \%$ for cyhalofop-butyl (S.D. $=3.8, \mathrm{n}=4)$. The determination curve for thiobencarb was $\mathrm{y}=46594 \mathrm{x}+348.72$ $\left(\mathrm{R}^{2}=0.9907\right)$; for pyributicarb, $\mathrm{y}=31602 \mathrm{x}+1275.2\left(\mathrm{R}^{2}=\right.$ 0.993); for cyhalofop-butyl, $\mathrm{y}=11689 \mathrm{x}+4607.8\left(\mathrm{R}^{2}=\right.$ $0.9987)$, and $y=27263 x+25830\left(R^{2}=0.9943\right)$ for mefenacet.

\subsection{Data analysis}

Dissipation rates were calculated using simple first-order kinetics (SFOK). The equation $\mathrm{C}=\mathrm{C}_{0} \mathrm{e}^{-\mathrm{kt}}$ was used for the first order kinetics, where $\mathrm{C}$ is the amount of herbicide $(\mathrm{mg} / \mathrm{L}$ water $)$ at time $\mathrm{t} ; \mathrm{C}_{0}$ is the amount of herbicide $(\mathrm{mg} / \mathrm{L}$ water) at time 0 ; $\mathrm{k}$ is the rate constant $\left(\mathrm{day}^{-1}\right)$ and $\mathrm{t}$ is the time (day). Initial concentrations of herbicide $\left(\mathrm{C}_{0}\right)$ were calculated on the basis of the total amount of water (in liters) in the paddy field at the time of application and the total amount of herbicide active ingredient (gm) applied, assuming that $100 \%$ of active ingredient had been dissolved in the water. The dissipation rate constant (k) was calculated by linear regression from the transformed first-order rate equation, $\ln \mathrm{C}=\ln \mathrm{C}_{0}-\mathrm{kt}$. Half-life $\left(\mathrm{DT}_{50}\right)$ was calculated using the equation $-\log (2) / \mathrm{k}[12]$. Data were analyzed using SPSS 11.0 for Windows.

\section{RESULTS}

\subsection{Herbicide concentration in paddy water}

No herbicides were present in the farm paddy water and experiment before application. Figure 2 shows the concentration of herbicides detected in Farm A and the corresponding experiment of herbicide containing thiobencarb and mefenacet at different time intervals. In the farm paddy, about $98 \%$ of thiobencarb and $91 \%$ of mefenacet degraded within 1 day after application. In the experiment, 95\% of applied thiobencarb and $83 \%$ of mefenacet degraded within 1 day after application. However, the dissipation rate was more rapid after 7 days of application. Both the compounds were detected until 21 days after application in the farm paddy and 28 days after application in the experiment. The calculated half-life of thiobencarb and mefenacet, respectively, were 2.93 and 4.02 days in the farm paddy, and 6.89 and 4.86 days in the experiment. The $\mathrm{R}^{2}$ values were acceptable (Tab. II) for all the herbicides.

Along with mefenacet the herbicide pyributicarb was analyzed in Farm B. Figure 3 shows the dissipation pattern of these two herbicides in the farm paddy and the experiment. The dissipation rate of the two herbicides was faster in the farm paddy
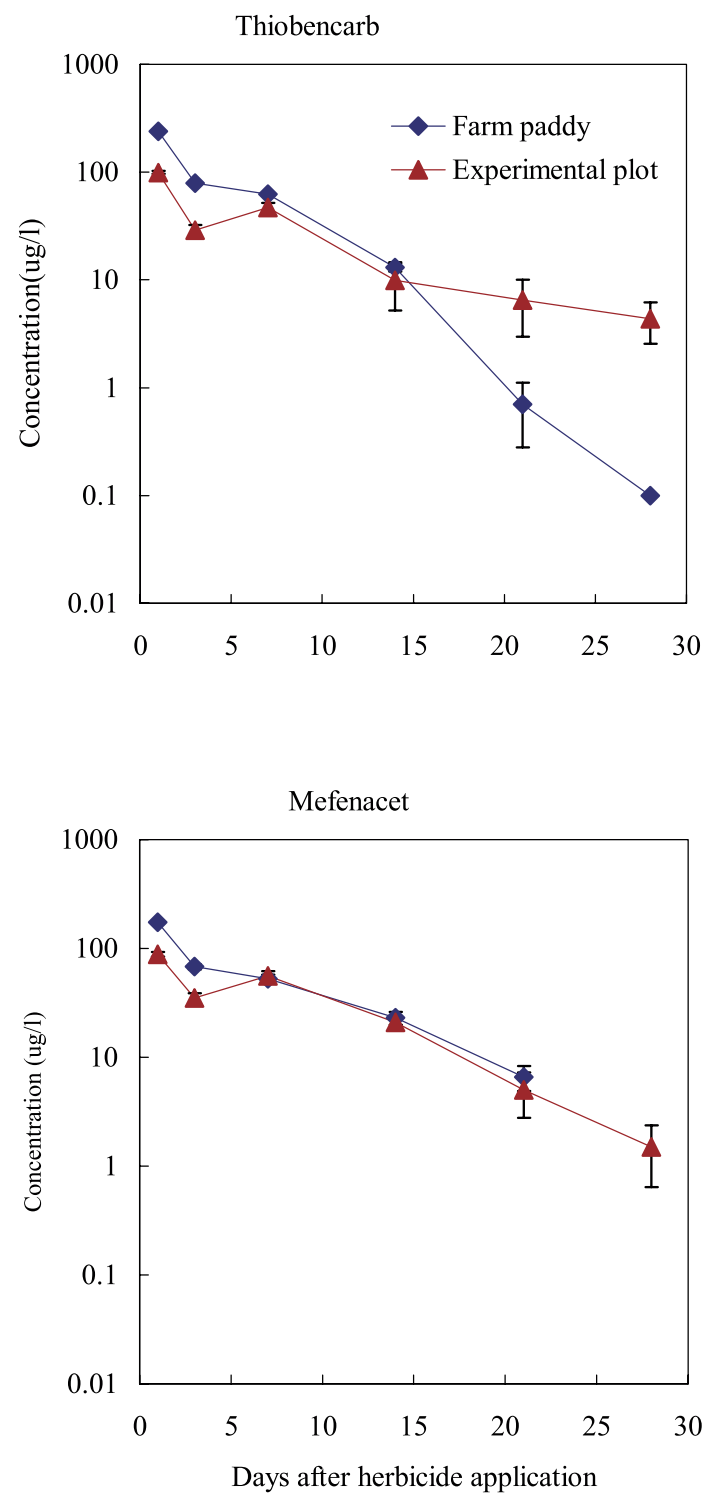

Figure 2. Herbicide dissipation pattern in Farm A and corresponding experimental plots. Data are given $\pm \mathrm{SD}(\mathrm{n}=4)$.

than the experiment (Tab. II). The calculated half-life of mefenacet and pyributicarb were 3.38 and 4.01 , and 4.42 and 6.13 , respectively, in the farm paddy and in the experiment.

The dissipation pattern of herbicides used in Farm $C$ is presented in Figure 4. In the experiment, cyhalofop-butyl was not detected even after 1 day of application but it was detected in the farm paddy until 7 days after application and was within the limit of detection, $0.1 \mu \mathrm{g} / \mathrm{L}$, until 14 days after application, with a calculated half-life of 0.99 days. Mefenacet persisted longer in the experiment, with a longer half-life than in the farm paddy (Tab. II).

\subsection{Herbicide concentration in drainage water}

Table III shows the herbicide draining from the three paddy farms. The drainage of the experimental plots was controlled 
Table II. Half-life $\left(\mathrm{DT}_{50}\right)$, disipation rate and $\mathrm{R}^{2}$ values of the study herbicides.

\begin{tabular}{lccccccc}
\hline & & \multicolumn{3}{c}{ Farm paddy } & \multicolumn{2}{c}{ Experiment } \\
\cline { 3 - 8 } & \multirow{2}{*}{ Herbicide used } & $\mathrm{k}$ & $\mathrm{R}^{2}$ & $\mathrm{DT}_{50}$ & $\mathrm{k}$ & $\mathrm{R}^{2}$ & $\mathrm{DT}_{50}$ \\
\hline Farm A & Mefenacet & 0.0749 & 0.9504 & 4.02 & 0.0619 & 0.9526 & 4.86 \\
& Thiobencarb & 0.1028 & 0.9707 & 2.93 & 0.0437 & 0.8605 & 6.89 \\
\multirow{2}{*}{ Farm B } & Mefenacet & 0.0846 & 0.889 & 3.38 & 0.0681 & 0.9988 & 4.42 \\
& Pyributicarb & 0.0748 & 0.833 & 4.01 & 0.049 & 0.8673 & 0.9818 \\
& Mefenacet & 0.0992 & 0.819 & 3.04 & 0.0678 & & 4.43 \\
& Cyhalo fop-butyl & 0.3035 & 0.999 & 0.99 & & & \\
\hline
\end{tabular}

$\mathrm{DT}_{50}=$ half-life (in days); computed using the equation $-\log (2) / \mathrm{k} . \mathrm{k}=$ dissipation rate; slope of the regression lines.
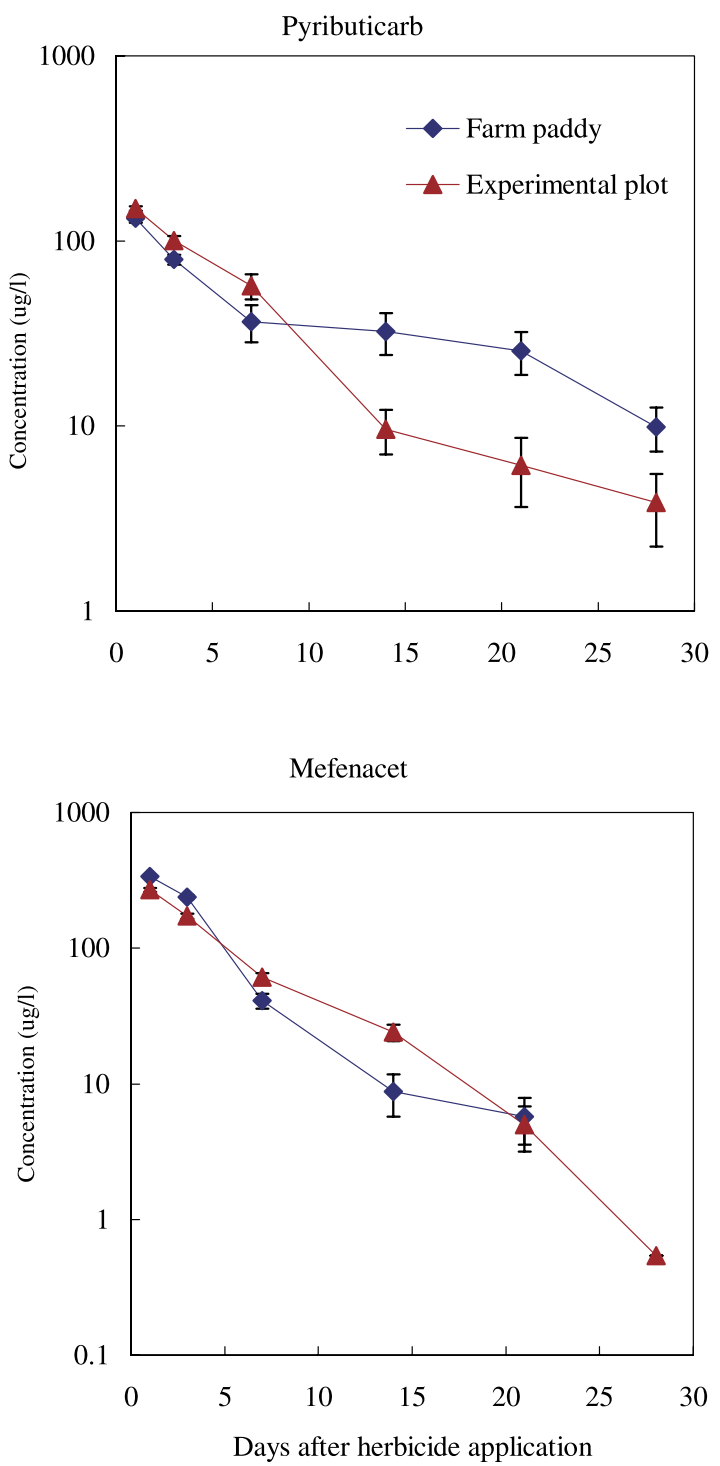

Figure 3. Herbicide dissipation in Farm $\mathrm{B}$ and corresponding experimental plots. Data are given $\pm \mathrm{SD}(\mathrm{n}=4)$.

until the detection of herbicide in the water. In the drainage water of Farm A, both the herbicides mefenacet and thiobencarb were present until 14 days after application. The detection
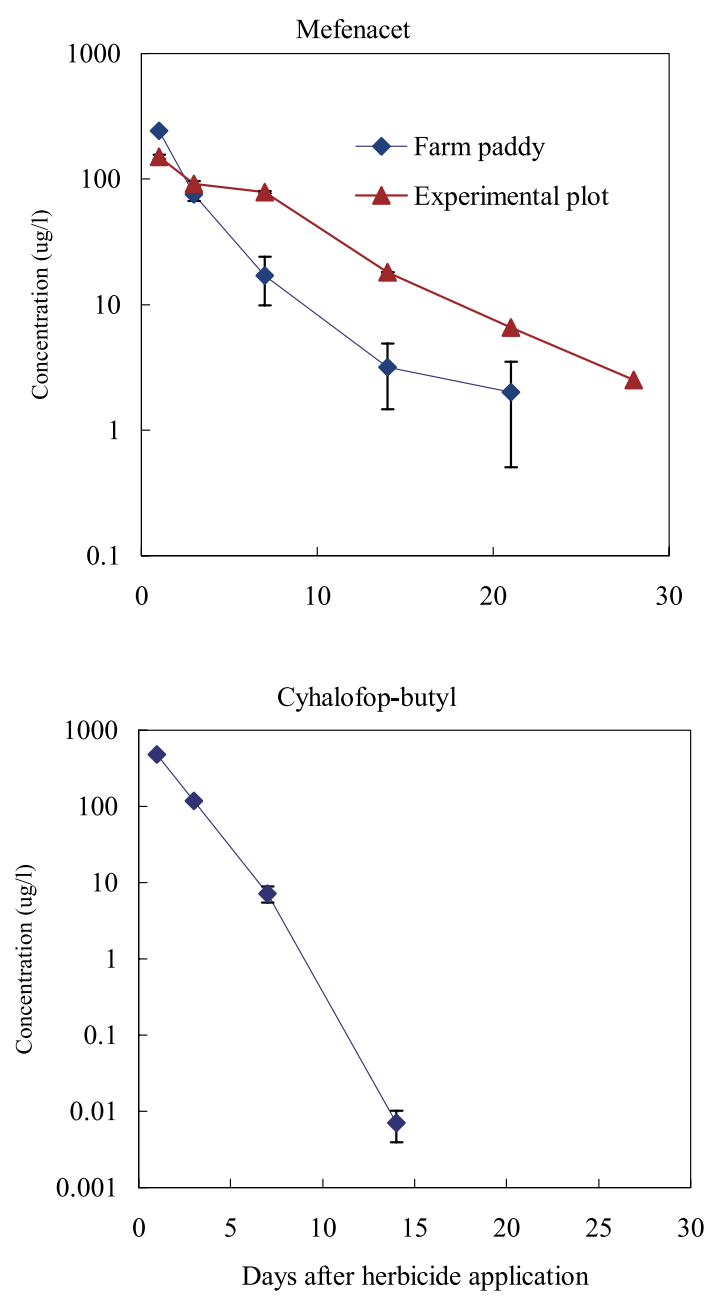

Figure 4. Herbicide dissipation in Farm $\mathrm{C}$ and corresponding experimental plots. Data are given \pm SD $(n=4)$.

amount went below $0.01 \mu \mathrm{g} / \mathrm{L}$ after 7 days for mefenacet and 3 days for thiobencarb. Pyributicarb and mefenacet were present until 14 days after application in the drainage water of Farm B. Mefenacet in the drainage water of Farm $\mathrm{C}$ was present until 21 days after application. There were significant relationships between the herbicide concentrations in paddy water and in drainage water. 
Table III. Herbicide concentration in the drainage water of the farm paddy and cumulative rainfall on the sampling dates.

\begin{tabular}{|c|c|c|c|c|c|c|c|c|}
\hline \multirow{3}{*}{ DAH } & \multicolumn{2}{|c|}{ Farm A } & \multirow{2}{*}{$\begin{array}{c}\text { Cumulative } \\
\text { rainfall }\end{array}$} & \multicolumn{2}{|c|}{ Farm B } & \multirow{2}{*}{$\begin{array}{c}\text { Cumulative } \\
\text { rainfall }\end{array}$} & \multirow{2}{*}{$\begin{array}{c}\text { Farm C } \\
\text { Mefenacet }\end{array}$} & \multirow{2}{*}{$\begin{array}{c}\text { Cumulative } \\
\text { rainfall }\end{array}$} \\
\hline & Mefenacet & Thiobencarb & & Mefenacet & Pyributicarb & & & \\
\hline & \multicolumn{2}{|c|}{$\mu \mathrm{g} \mathrm{L}^{-1}$} & $\mathrm{~mm}$ & \multicolumn{2}{|c|}{$\mu \mathrm{g} \mathrm{L}^{-1}$} & $\mathrm{~mm}$ & $\mu \mathrm{g} \mathrm{L}^{-1}$ & $\mathrm{~mm}$ \\
\hline 1 & 162.964 & 179.168 & 13 & 32.44 & 41.003 & 13 & 242.05 & 19 \\
\hline 3 & 117.349 & 3.77 & 97 & 46.557 & 39.715 & 49 & 44.478 & 55 \\
\hline 7 & 0.707 & $<0.01$ & 110 & 18 & 7 & 133 & 6.814 & 139 \\
\hline 14 & $<0.01$ & $<0.01$ & 111 & $<0.01$ & 4 & 140 & 2.688 & 147 \\
\hline 21 & - & - & 115 & - & - & 141 & $<0.01$ & 147 \\
\hline $\begin{array}{l}\text { Correlation between } \\
\text { paddy water }\end{array}$ & 0.8774 & 0.7975 & & 0.7189 & 0.6288 & & 0.9845 & \\
\hline concentration $\left(\mathrm{R}^{2}\right)$ & $(P<0.005)$ & $(P<0.01)$ & & $(P<0.006)$ & $(P<002)$ & & $(P<0.000)$ & \\
\hline
\end{tabular}

DA $\mathrm{H}=$ Days after herbicide application

\section{DISCUSSION}

The dissipation pattern of mefenacet was more or less similar in all the farm paddies. The dissipation rate was faster in Farm B and Farm $\mathrm{C}$ than in Farm A, as well as in the corresponding experiments. There was significant difference in dissipation of mefenacet between Farms A and B $(P<0.007)$, Farms B and $\mathrm{C}(P<0.05)$ and Farms $\mathrm{A}$ and $\mathrm{C}(P<0.001)$. Mefenacet concentration in paddy water peaked over the second day and its dissipation was rapid until the third (farm paddies) to fourth week (experiments), and the half-life of mefenacet varied from 3.04 to 4.86 days. The underlying cause might be that mefenacet has a lower water solubility $(4 \mathrm{mg} / \mathrm{L})$ and higher adsorption coefficient $\left(\mathrm{K}_{\mathrm{d}}=24.07\right)$, and for this reason much of its residues could have been adsorbed by the soil, leaving only a small portion in the water [5]. According to the study of Ferdinand et al. [5], mefenacet dissipation rates peaked at 2 to 3 days after application and were rapid until the fourth week, with a half-life of 3.1 to 4.1 days; and also there was no evidence of residue build-up, due to continuous application in the same plot. Watanabe and Takagi [20] reported that mefenacet peaked on the third day and was detected until the fourth week in their model paddy field, the rate of degradation of pyributicarb being slower with lower level concentration. Our study also reveals that the maximum concentration of the mefenacet in the farm paddies as well as in the experiment was at 1 day after herbicide application and the dissipation rate was fast until the 3rd week in the farm paddies, but up until the 4th week in the experiment. Due to lower initial concentrations and water drainage, our study showed more rapid dissipation of mefenacet than the studies of Ferdinand et al. [5] and Watanabe and Takagi [20]. In farm paddies, mefenacet degraded more rapidly than in the experiments $(P<0.007$ for Farm A; $P<0.039$ for Farm B and $P<0.01$ for Farm $C$ ). There was no significant difference between the concentration of pyrbuticarb in the farm paddy and the experiment $(P<0.569)$.

Thiobencarb dissipated more rapidly in the farm paddy than in the experiment $(P<0.003)$. A considerable amount of thiobencarb in the drainage channel at $1 \mathrm{DAH}$ indicates the runoff loss through drainage water from the paddy fields and this may cause quick dissipation in the paddy water. Ross and Sava [17] reported significantly longer persistence in a paddy field where thiobencarb was applied as granules and the water was held for a required 6 days. The concentration of thiobencarb peaked in paddy water on day 4 at $576 \mathrm{ppb}$ and did not decline significantly during the holding period [13]. However, our study farm could not maintain a water-holding period; there was rainfall even on the day of herbicide application (Tab. III). As a result, the water flowed from the paddy field to the drainage channel. The quick dissipation phenomenon in the farm paddy water resulted in a shorter half-life of thiobencarb: 2.93 days, compared with 6.89 days in the experiment. Crosby [3] reported that the field dissipation half-life of thiobencarb is 5 to 7 days. The persistence period of thiobencarb at $21 \mathrm{DAH}$ in the farm paddy and 28 DAH in the experiment is congruent with the study of Watanabe et al. [22], where it was reported that the maximum concentration in paddy water was $380 \mathrm{ppb}$, and this declined to below 1 ppb between 25 and 30 days. Similar degradation rates were reported for molinate, thiobencarb and bensulfuron methyl in California paddy waters [2]. The same study of the California Rice Commission reported maximum thiobencarb degradation on the 2nd day after application, and this decreased rapidly within 10 days after application, suggesting that a minimum water-holding period is required to reduce the pesticide draining from the paddy water.

In Farm C, the half-life of cyhalofop-butyl, 0.99 days, was much higher in the paddy water, indicating longer persistence in the water than the expected 1.4-5.3 hours. The lowest measured ecotoxicological end-point for cyhalofop-butyl identified in the dossier was $0.134 \mu \mathrm{g} / \mathrm{L}$, and the predicted environmental concentration (PEC) in the paddy water was $300 \mu \mathrm{g} / \mathrm{L}$ and for adjacent surface water, $100 \mu \mathrm{g} / \mathrm{L}$ [4]. Although mefenacet was present in the drainage channel, no cyhalofop-butyl was found. Further study is needed to examine the details of the dissipation of cyhalofop-butyl.

A considerable amount of herbicides were detected in the drainage water from the paddy fields, which correspond to the paddy water concentration representing herbicide runoff from the farm paddy (in Farm A; $P<0.01$ for thiobencarb; $P<0.005$ 
for mefenacet; in Farm B, $P<0.006$ for mefenacet; $P<0.002$ for pyributicarb; and in Farm $C P<0.000$ for mefenacet). Sudo et al. [18] found that the runoff of the herbicides was concentrated in the application period due to excessive rainfall. Inao et al. [8] evaluated the pesticide paddy field model (PADDY) under two different conditions of the water management practices, continuous irrigation and drainage, and water-holding management that regulates drainage; they performed the experiment with molinate and simetryn. The concentration of both herbicides in paddy water was at the same level during the first day after application on both fields. After the second day, herbicide concentrations in the field of continuous irrigation and drainage were lower than those in the field of water-holding management. The concentration of cinosulfuron in paddy water dropped due to the effect of water flow after the opening of the water gate [6]. Many studies have reported the runoff of herbicides to the surface water in the paddy season $[15,18,19]$. Quick dissipation and the presence of herbicides in the drainage channel may be due to the effect of water runoff from the farm paddies. This may result in a reduction in the efficiency of the herbicide at killing weeds, which may in turn lead to the use of more herbicides.

In Japan, the maximum limit of some pesticides has been set up in August 2001. According to the Environmental Agency of Japan the average concentration which may not be exceeded of mefenacet, thiobencarb, pyributicarb and cyhalofop-butyl in paddy water within 150 days of applications are, respectively, $0.09 \mathrm{mg} / \mathrm{L}, 0.2 \mathrm{mg} / \mathrm{L}, 0.2 \mathrm{mg} / \mathrm{L}$ and $0.06 \mathrm{mg} / \mathrm{L}$. The maximum limit of thiobencarb in drainage channels and public waterways (such as streams and rivers) is $0.02 \mathrm{mg} / \mathrm{L}$, and of mefenacet in public waterways, $0.009 \mathrm{mg} / \mathrm{L}$ [11]. The maximum limits for pyributicarb and cyhalofop-butyl in public waterways are not set yet.

In conclusion, it could be said that our study farm applied herbicides using the appropriate dosage which have a short dissipation half-life in farm paddy water. The dissipation rates were slower than those in the experiment but did not persist for a length of time that may be harmful to the environment. The farm paddies have no effective drainage control measures. This was reflected in the presence of a considerable amount of herbicides in the drainage channel, even though these disappeared more rapidly than in the paddy water. Water management systems control the pesticide movement into the larger surface water bodies. In the farm paddies we studied, the recommended holding period of 10 days after application was not strictly maintained. Therefore, the herbicide ran off and/or overflowed through the drainage water. To minimize environmental pollution it is important to reduce concentrations in waterways to levels at or below acceptable concentrations, allowing time for their breakdown within the paddy field before any water is released into waterways. However, the presence of residues in drainage water indicates the potential of paddy water runoff to affect the surface water quality and the aquatic environment. The target value of these herbicides in the paddy field and public waterways may not be exceeded after 150 days of application as set by the Environmental Agency of Japan.

Acknowledgements: The authors would like to thank Sasakawa Scientific Research Grant from the Japan Science Society for their contribution to funding this research. We are heartily grateful to Mr. Martin Stephen Ward (UK) for his cooperation in editing the manuscript.

\section{REFERENCES}

[1] Ambrus A., Lantos J., Evaluation of the Studies on Decline of Pesticide Residues, J. Agric. Food Chem. 50 (2002) 846-851.

[2] California Rice Commission CA Rice. Water Supply in Relation to Rice Farming. URL:http://www.calrice.org/environment/balance-sheet/chap2.html.

[3] Crosby D.G., The fate of herbicides in California rice culture, in: IUPAC Pesticide Chemistry: human welfare and the environment, Pergamon Press, New York, 1983, pp. 339-346.

[4] European Commission (EU), Health and Consumer Protection Directorate General. Opinion of the scientific committee on plants on the evaluation of cyhalofop-butyl (IDE - 537) in the context of council directive 91/414/EEC for placing plant protection products on the market. SCP/CYHALO/002 - Final (2001).

[5] Ferdinand F.F., Takagi K., Ishizaka M., Usui K., Patterns and Rate of Dissipation of Pretilachlor and Mefenacet in Plow Layer and Paddy water under Lowland Field Conditions: A three-year study, J. Pestic. Sci. 25 (2000) 94-100.

[6] Ferrero A., Vidotto F., Gennari M., Nègre M., Behavior of cinosulfuron in paddy surface waters, sediments, and ground water, J. Environ. Qual. 30 (2001) 131-140.

[7] Hayase K., Hashimoto A., Kohguchi T., Behavior of pesticides in paddy Fields in Hiroshima Prefecture, J. Environ. Sci. 12 (1999) 159-170. (In Japanese with English Abstract.)

[8] Inao K., Ishi Y., Kobara Y., Kitamura Y., Prediction of pesticide behavior in paddy field by water balance on the water management using pesticide paddy field model (PADDY), J. Pestic. Sci. 26 (2001) 229-235.

[9] Inao K., Ishi Y., Kobara Y., Kitamura Y., Landscape scale simulation of pesticide behavior in river basin due to runoff from Paddy Fields using Pesticide Paddy Field Model (PADDY), J. Pestic. Sci. 28 (2003) 24-32.

[10] Itagaki N., Nagafuchi O., Takimoto K., Okada M., Fate of pesticides in a shallow reservoir, Water Sci. Technol. 42 (2000) 217-222.

[11] Japan Plant Protection Association. Various standards for agricultural chemicals concerning water quality set by the Ministry of Public Health and Welfare, Jap. Pestic. Handbook (2001) 811-817 (in Japanese).

[12] Kohno K., Calculation of half-life, Coll. Exp. Data Special Bull. Kyushu Agric. Exp. Station 68 (1986) (in Japanese).

[13] Mabury S.A., Cox J.S., Crosby D.G., Environmental fate of rice pesticides in California, Rev. Environ. Contam. T. 147 (1996) 71-117.

[14] Maru S., Study on the behavior and fate of pesticides in aquatic environment, Special Bull. Chiba Agric. Exp. Station 18 (1991) 1-62 (in Japanese with English abstract).

[15] Mitobe H., Ibaraki T., Tanabbe A., Kawata K., Sakai M., Kifune I., Variation of pesticides in river flowing through paddy fields area, J. Environ. Chem. 9(1999) 311-320 (in Japanese with English summary).

[16] Parveen S., Nakagoshi N., Kimura A., Perceptions and Pesticides Use Practices of Rice Farmers in Hiroshima Prefecture, Japan, J. Sustain. Agric. 22 (2003) (in press).

[17] Ross L.J., Sava R.J., Fate of thiobencarb and molonate in rice fields, J. Environ. Qual. 15 (1986) 220-224.

[18] Sudo M., Kunimatsu T., Okubo T., Concentration and loading of pesticide residues in Lake Biwa basin (Japan), Water Res. 36 (2002) 315-329.

[19] Watanabe A., Mitobe H., Kawata K., Sakai M., Monitoring of herbicides in river water by gas chromatography mass spectrometry and solid phase extraction, J. Chromatogr. A 754 (1996) 159-168.

[20] Ueji M., Inao K., Rice paddy field herbicides and their effects on the environment and ecosystems, Weed Biol. Manag. 1 (2001) 71-79.

[21] Watanabe H., Vu H.S., Kakagawa Y., Motobayashi T., Kato M., Suzuki S., The Best Management Practicefor Controlling Pesticide Runoff from Paddy Field, Proceedings of the 3rd International Symposium Environmental Management, 2002.

[22] Watanabe H, Tagaki K., A simulation models for predicting pesticide concentrations in paddy water and surface soil. 1. Model development, Environ. Technol. 21 (2000) 1379-1391. 